\title{
LAW AND BEHAVIORAL SCIENCE
}

\author{
WALTER BERNs*
}

\section{INTRODUCTION}

Behavioral science, which has only recently become a subject of discussion in legal journals, has had its greatest impact on the newer social sciences, especially sociology. This success may be attributed either to the ability of the behavioral approach to answer the questions posed in sociology or to the willingness of sociologists to restrict their questions to those that can be answered by behavioral research; in either case, it is a fact that sociology today has almost no existence except as a behavioral science. It is wholly committed to the research methods and to the basic premise of behavioral science. ${ }^{1}$

This new approach has had a relatively lesser impact on political science, the discipline closest to law. Despite its success in sociology and social psychology, and despite the commitment to it on the part of many well known political scientists, it has not yet succeeded in capturing the profession, or, at least, in subduing all opposition within the profession. This might be attributed to the fact that political science, like law, is old, the carrier of traditions that date back to classical antiquity, and that traditional disciplines tend to resist innovation, sometimes merely because of an attachment to what is old and therefore familiar. Those who have publicly opposed the new behavioral political science have not, of course, knowingly chosen this non-rational ground on which to place their opposition; they have given reasons, but perhaps not in every case good reasons. They in turn have been ridiculed, but perhaps not in every case justifiably. At least one of them, Bernard Crick, the British author of The American Science of Politics," has been dismissed as "ill-

- Ph.D. 1953, University of Chicago. Associate Professor of Government, Cornell University. Author, Freedon, Viriue aNd the First Axendment (I957); co-author, Essays on the Scientific Study of Pourncs (1962). Contributor to legal and political science journals.

'See Easton, The Current Meaning of "Behavioralism" in Political Science, in Janes C. Chardesworth (ED.), The Limits of Beinvioralism in Political Science 7-8 (Ig62), for a description of the "intellectual foundation stones" on which behavioralism is built. Dahl, The Behavioral Approach in Political Science: Epitaph for a Monument to a Successful Protest, 55 AM. Pot. Scr. REv. 763 (I961), says it is easier to describe what behavioral science is not than to say what it is. Dahl discusses the difficulty in defining the term, behavioral science, and adopts the definition, or understanding, of David Truman. This, he states as follows: "Political behavior is not ... a specialty, for it represents rather an orientation or a point of view which aims at stating all the phenomena of. government in terms of the observed and observable behavior of men.... The developments underlying the current interest in political behavior imply two basic requirements for research. In the first place, research must be systematic. . . This means that research must grow out of a precise statement of hypotheses and a rigorous ordering of evidence.... In the second place, research in political behavior must place primary emphasis upon empirical methods.... The ultimate goal of the student of political behavior is the development of a science of the political process....'" Dahl, supra, at 767 . In the. last part of this-paper we shall be using the terms social science and social scientists, but as David Easton says, "we might argue that there is really nothing in a name, that the oscillation in nomenclature between social sciences and behavioral sciences today is inconsequential and irrelevant." Easton, stipra, at zo.

a Bernard Crick, The American Sctence of Politics (1959). 
informed and ill-tempered" by no less a person than the Executive Director of the American Political Science Association. 3 Others have been called "naive" and their ideas "primitive." From the other side has come the charge that the work of at least some behavioral scientists is no more than "science fiction" or "numerology" marked by "banality." "The Executive Director of the APSA speaks of the dispute in the past tense: 'The 'war' between the behavioralists and 'traditionalists' was short-lived," he writes confidently, and will not "recur." But his confidence rests on the opinion that "the behavioral approach ... represents no sharp break with the past," an opinion not shared by all his colleagues, traditionalists or behavioralists.

Furthermore, shortly before his prediction of a peaceful (and behavioral) future appeared, there also appeared the most critical and least compromising of all the anti-behavioral studies: Essays on the Scientific Study of Politics. ${ }^{6}$ And in the first review of this book in a professional journal, its authors are ridiculed by behavioral scientist Angus Campbell as self-proclaimed "apostles of revealed truth [unable] to understand the reasoning of those who fall from grace." Campbell charges them further with being unable to evaluate the new political science on its merits, but only "within the limits of their own system of thought, within which, of course, it is corrupt and untenable."7 These are serious charges, and, if true, it would be difficult to avoid the conclusion that even the most assiduous effort to judge the new political science within its own terms is doomed to fail, and that there can be no joining of the important issues in the debate, even though the debate itself continues. ${ }^{8}$

The purpose of this paper is to determine what role, if any, behavioral science can play in the law, or in legal studies. There is a good deal of uncertainty about the extent to which the behavioral approach will or should replace the traditional one, and about what, precisely, the behavioral scientist promises to contribute to the study and practice of law. But the promises, though often vague, are designed to raise high hopes. Glendon Schubert, for example, has said that unless the behavioral approach is adopted, "the moribund state of catalepsy that characterizes public law study today [will very likely pass] into rigor mortis before the end of another generation." Presumably, not every area of legal studies is threatened with so

\footnotetext{
${ }^{8}$ Kirkpatrick, The Impact of the Behavioral Approach on Traditional Political Science, in AustiN Ranney (ED.), Essays on the Behavioral Study of Politics 1, 28 (1962).

'Roche, Political Science and Science Fiction, 52 AM. PoL. Scr. Rev. I026, 1028 (1958).

Kirkpatrick, supra note 3 , at 27-28.

- Herbert J. Storing (Ed.), Essays on the Scientific Study of Politics (1962). Indeed, even as this paper was being written, still another study appeared: James C. Crarlesworth (ED.), Tire Limits of Behavioralisas in Political Science (rg62).

Book Review, 27 AM. Soc. Rev. 702, 703 (1962).

8 The reader will, of course, have to judge for himself whether Campbell's charges are justified, but it might help him to know that Campbell is himself one of the authors whose work as a new political scientist is subjected to a very close and a very critical analysis in the very book he reviews. Campbell (or the book review editor of the American Sociological Review) does not appear to give much weight to a principle that lawyers have regarded as basic: nemo debet esse judex in propria causa.

"Glendon Schubert, "The Study of Judicial Decision-Making as an Aspect of Political Behavior," a paper delivered at the convention of the American Political Science Association, St. Louis, Mo., Sept. $4-6,1958$.
} 
desperate a fate, but all or nearly all are promised a brighter future with behavioral science.

Behavioral science promises, for example, more expert testimony, especially in those areas where courts have traditionally been required to rely on judicial notice; it promises a new understanding of the factors responsible for decisions; it promises computers designed to do the work of judges more effectively than the judges themselves; it promises, finally, a method of solving the great and intractable problems of jurisprudence. With such a prospect, offering such fruitful labors, it is not difficult to understand why a major law school has established a behavioral science program within its curriculum, ${ }^{10}$ or why an increasing number of political scientists working with legal materials have adopted the behavioral approach, or why it is predicted that this will be "the focus of interest and activity of the coming generation. ..."11 Thus, what we are dealing with in this paper represents the wave of the future, and we have been taught by Marx, among others, that to resist the wave of the future is to court disaster. ${ }^{12}$

\section{Behavioral Science as Game Theory}

No one has been more active in the effort to introduce behavioral science to legal studies than Glendon Schubert. Not only does he deplore the fact that public law had been relatively immune to behavioral science, thus slipping "out of the main stream of conceptual and methodological developments in political science, ${ }^{, 13}$ but he sets out to do something about it. "How can we ever hope to create a political science of public law" if we continue to accept, for both teaching and research, models "borrowed almost exclusively from three other professions: law, history, and

${ }^{10}$ Donnelly, Some Comments Upon the Law and Behavioral Science Program at Yale, 12 J. LegaI ED. 83 (1959); Schwartz, The Law and Behavioral Science Program at Yale: A Sociologist's Account of Some Experiments, id. at 9x; Katz, The Law and Behavioral Science Program at Yale: A Psychiatrist's First Impressions, id. at 99.

${ }^{11}$ Schubert, The Study of Judicial Decision-Making as an Aspect of Political Behavior, 52 AM. PoL. Sci. REv. 1007 (1958).

${ }_{12}$ There is an immense literature on sociology and law, sociological jurisprudence, and legal realism that, despite its relation to the subject, cannot be discussed within the space limits of this paper. See, for example, George Gurvitch, Sociology of Law (I942); Eugen Ehrlich, Fundamental Principles of THE SOCIOLOCY OF LAw (1936); N. S. TinashefF, AN InTRODUCtion To THE Soctology of LAw (I939); and the most recent volume in this category, F. JAMEs DAvis, Henry H. Foster, JR., C. RAY JEFFERY \& E. Eugene Davis, Society and the Law: New Mesnings for an Old Profession (1962). "The main purpose of this book on law and its context," write the authors of the work last cited, "is to persuade the student of sociology that law is relevant to an understanding of society and the student of law that it is always pertinent to look at the social purposes and consequences of a legal rule." Id. at 396 . One cannot help wonder why sociologists have to be persuaded that "law is relevant to an understanding of society," or where the authors thoughe they could find a student of law who has to be reminded that it is "always pertinent to look at the social purposes and consequences of a legal rule."

Nor is it possible to deal here with the most familiar attempts to combine psychiatry and law, best ilustrated in the work of the Gluecks at the Harvard Law School. For a recent statement of what they regard as the contributions of psychiatry to the law, see Sheldon Gldeck, Law aNd Psychatzx: Cold WAR OR ENTENTE CORDIALE? (1962).

${ }^{18}$ Glendon A. Schubert, Quantitative Analysis of Judicial Behuvior 2 (1959). 
philosophy?"14 Nor does he confine himself to exhortations addressed to his colleagues; in true pioneer fashion he leads the way, not, as is so frequently the case with behavioral scientists, by writing theoretical works concerned with how the empirical studies might be done, but by actually producing the studies. These studies are intended to show public lawyers, and anyone else interested in "methodological developments," that the "political behavior of judges is an appropriate and fertile field for further experimentation with the kinds of concepts and research techniques" familiar to behavioral scientists. ${ }^{15}$

Unfortunately, it is frequently difficult to state precisely what the intentions of the behavioral scientists are. Schubert says one thing and Frank A. Pinner, the Director of the Bureau of Social and Political Research at Michigan State University, under whose auspices Schubert's book was published, says another in his Foreword to the book. Pinner essays an explication, of sorts, of Aristotle's Physics, as an example of "naive" science, and contrasts it unfavorably with modern or advanced science. In the course of this he says: "All early science inquires into the 'nature' of things and tries thereby to explain behavior; all advanced science deals almost exclusively with relations." ${ }^{16}$ Consistent with this statement, the Foreword is a disclaimer of any intention on Schubert's part to "explain behavior," or explore motivation, whereas Schubert himself describes this as his primary concern, and emphasizes his point by underscoring the word motivation. "Our primary concern is with the motivations which lead individual [judges] to choose, in their conjoint voting behavior, to select certain alternatives (i.e., preferred outcomes) rather than others." Instead of asking "What decisions has the Supreme Court made?", or what decisions it ought to make, he asks "Why (and to a lesser extent how) does the Supreme Court make the decisions that it does?"17 With this purpose in mind, Schubert has attempted to demonstrate the utility of "game analysis." "The judicial process," he says, "is tailor-made for investigation by the theory of games."18

Game theory, invented by mathematicians, is intended to provide a model "for describing and predicting" behavior under certain specified conditions. Richard C. Snyder, whom Schubert accepts as an authority on the subject, describes game theory as follows: $:^{19}$

${ }^{24}$ Id. at 4 .

${ }^{15}$ Id. at 9-10.

${ }^{16}$ Id. at viii. For an explication of Aristotelian physics, in the form of an imaginary address by Aristotle to an assembly of modern physicists, see Kurt RIEzLER, Physics AND ReaLity (1940).

${ }^{27} 7 d$. at II.

${ }^{18}$ Schubert, The Study of Judicial Decision-Making As An Aspect of Political Behavior, 52 AM. Pot. Sa. REv. 1007, I022 (1958).

${ }^{19}$ Snyder, Game Theory and the Analysis of Political Behavior, in S. StDNEy Ularer (ED.), Introductory Readings in Polttical Behavior $27 \mathrm{I}$ (1961). The essay appeared originally in Resanraci Frontiers in Politics and Governasent: Brookings Lectures 1955, at 76.

The various terms employed in game theory are defined by Snyder as follows: strategy means a complete plan of action, one that "cannot be upset by an opponent or by nature." "If only a single strategy happens to be optimal for each player, it is called a pure strategy. If on successive plays, a different strategy is required to minimize loss and maximize gains, the strategy is said to be mixed." Pay-of is what the game is worth in "terms of probabilities fulfilled, in terms of winnings and losses, in terms of positive 
The purpose of game theory is two-fold: to formulate mathematically complete principles that will specify what is rational behavior in certain kinds of social situations and, on the basis of such principles, to isolate the general characteristics of such behavior. Thus it is a method of analysis and a method of selecting the best courses of action. The social situations are those that are goal-oriented-action is geared to accomplishment of certain ends. These situations call for rational behavior, i.e., behavior designed to produce decisions and courses of action embodying the least costly way to achieve goals or to keep losses to a minimum given operating conditions.... What action is rational when all relevant possibilities are known and the outcome is not determined by any one participant? Game theory attempts to answer this question by developing a mathematical theory for choice-making among alternative courses of action when it is impossible to control all the factors that govern outcomes because of the actions of others. It is to be noted that the term rational applies only to action, not goals....

It must be emphasized that the "game" is an analytic device, a model for describing and predicting behavior the properties of which are specified by the model.

Game theory, then, is one of the techniques adopted by Schubert to understand judicial motivation; with a "game" as a model, he tests the "empirical ingredients" (the votes of the judges and the postulated "utility"-i.e., the object of play), with the view to constructing a theory of judicial behavior. This theory can then be tested by making predictions on its basis. It should be understood that Schubert and others do not analyze behavior in order to make predictions; they make predictions in order to test the validity of their analyses. In the words of Samuel J. Eldersveld: ${ }^{20}$ "If [the] objective . . . is to understand, it is eventually necessary to predict. For how can one be certain of understanding behavior, unless he is willing to make predictive judgments?"

One game Schubert plays is the so-called "Certiorari Game." "Do Supreme Court justices combine into a bloc with the deliberate objective of forcing upon the rest of the Court the consideration of an issue which the bloc wants decided in a particular way?"21 He takes for consideration the Court's decisions in Federal Employer's Liability Act cases during the period I942-1948. ${ }^{22}$

At that time, the certiorari bloc consisted of Murphy, Rutledge, Black, and Douglas. If we assume that the objective of the bloc was to maximize the number of decisions favorable to workmen's claims, game theory can prescribe how the bloc should behave rationally in order to accomplish this objective. Four justices are adequate to grant certiorari, but not (normally) to decide cases on the merits. It is assumed that, during this period, the remaining five justices had no fixed predispositions either toward or against the claimants. The only question in these cases is whether the trial court correctly

or negative progress toward avowed goals." The pay-off matrix is a calculation in mathematical terms and presented in "box fashion," of the pay-offs and is achieved by "plotting the strategies and their probabilities." Id. at 272-73.

${ }^{20}$ Eldersveld, Theory and Method in Voting Behavior Research, in Heinz Eulau, SaMuel J. Eldersverd \& Morris Janowitz, Polttical Behavior: A Reader in Theory and Research 273 (1956).

${ }^{21}$ Schubert, The Study of Judicial Decision-Making As An Aspect of Political Behavior, 52 AM. Por. Scr. REv. 1007, 1023 (1958).

22 Id. at 1023-24. 
evaluated the evidence; the cases turn, in other words, on questions of fact rather than law. ... the decision of the trial court has [either] been affirmed or reversed by a court of appeals, and either the plaintiff workman or the defendant railroad has petitioned the Supreme Court for certiorari. It is assumed that, since these cases turn only on the evaluation of evidence, there is an equal chance that any of the five uncommitted justices will vote either for or against a claimant if the court of appeals has disagreed with the trial court. Therefore, since the certiorari bloc needs to pick up only one additional favorable vote on the merits, the chances of its doing so should be $31 / 82$, for the only permutation of the five uncommitted members on which the bloc could lose would be for all five of the other justices to vote against the claimant.

Offhand, and without the benefit of mathematical computations, it would seem that if these four justices wanted "to maximize the number of decisions favorable to workmen's claims," the sensible thing for them to do would be always to vote in favor of the workmen's claims. According to Schubert, however, this is not the best strategy to employ. His game analysis, he says, proves that they should vote to grant certiorari when it is sought by the workman only when the appellate court has. reversed a judgment in favor of the workman: ${ }^{23}$

The certiorari bloc has a pure strategy: never to vote in favor of petitions filed by railroads, always to vote to grant certiorari in cases in which review is sought by workers and in which an appellate court has reversed a judgment in favor of the plaintiff, and always to vote for the petitioner on the merits. If the certiorari bloc follows its pure strategy, the Court should decide 97 per cent of the cases in favor of the claimants. ...

As a matter of fact, the payoff to the certiorari bloc during this period was 92 per cent ( 12 pro decisions and I con) in cases in which the bloc adhered to its pure strategy; of the II cases in which the bloc departed from its pure strategy by voting to grant certiorari for petitioners who had been two-time losers in the courts below 8 were pro and 3 were con, for a payoff of only 73 per cent.

The reason why the certiorari bloc should adopt this strategy instead of voting for the workmen all the time is explained by Schubert in his book, where the same certiorari game is explained at much greater length. Many of the petitions filed by workers are "frivolous," and in such cases it is likely that the bloc will find it more difficult to pick up the needed fifth vote; furthermore, there is always the chance that the bloc will antagonize the other members of the Court and thereby jeopardize "favorable decisions in the stronger cases." Essentially, Schubert is advising the use of discretion; but the proof of the pudding is in the eating, as the saying goes, and by using mathematics of a simple arithmetical sort, much more simple than the computations made by Schubert, it is easy to prove that Schubert is giving bad advice. In order to get into the spirit of the game, we shall adopt a simple box score, modeled after those found in the sports pages of any newspaper. (The figures are taken from Schubert's paragraph quoted above, or compiled from those given there.)

${ }^{28} I d$. at I024-25.

"Glendon A. Schubert, Quantitative ANalysis of Judictal Behavior 230 (1959). 


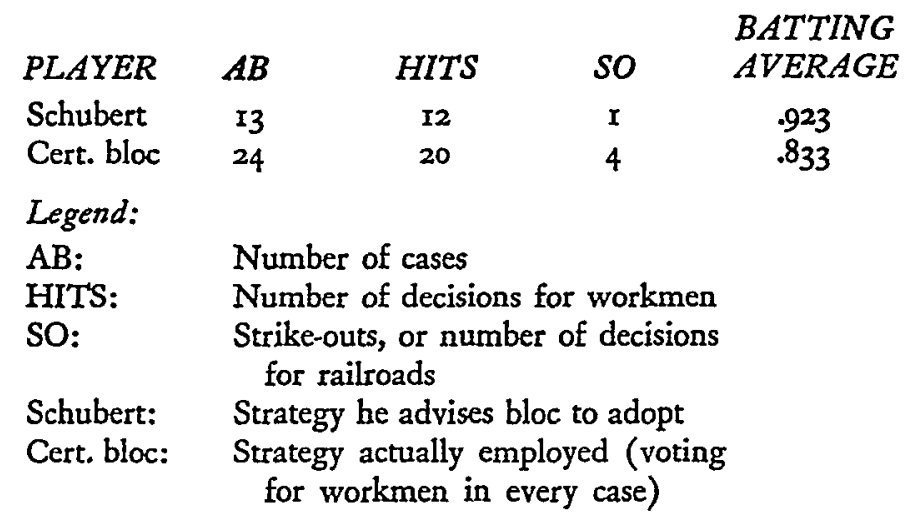

This demonstrates that the "pure strategy" would have rewarded the certiorari bloc with victories in ninety-two per cent of the cases, whereas the strategy actually employed gave them victories in only eighty-three per cent of the cases. But it also demonstrates that the "pure strategy" would have rewarded the bloc with twelve victories, whereas the strategy actually employed rewarded them with twenty victories. What is the purpose of the game, high batting average or total hits? In fact, Schubert changes the purpose of the game during the playing of it! He began by saying that the purpose of the game was to "maximize the number of decisions favorable to workmen's claims," but he demonstrates the superiority of his "pure strategy" in terms of batting average. In short, what we learn from game analysis is, you get a higher proportion of hits if you don't swing at bad pitches. It also proves, however, that you get more hits by swinging at more pitches. In his book Schubert admits this. By playing with the mixed strategy (swinging at more pitches), he says, "the bloc won a larger number of cases, but it also incurred a much higher proportion of losses than would have been expected if it had adhered to its pure strategy."25 Our conclusion is the same as the off-hand assumption we began with, now fortified by Schubert's game analysis: if the four justices want decisions favorable to the workmen, the sensible thing to do is to vote for the workmen.

Since Schubert seems unable to maintain a consistent view of the "utility" sought by the players, total hits or high batting average, there is no purpose in pursuing the analysis of this game any further. By voting for the workmen's claims in these cases, it would seem obvious that the four justices making up the so-called certiorari bloc were "motivated" by the desire to achieve a particular substantive result in these cases, which will surprise no one. His game analysis only succeeds in obscuring this fact from those who fail to read him closely. But Schubert also plays another game, this one involving a more complicated situation. He calls it the "Hughberts Game."

During the $193^{6}$ term of the Supreme Court, he writes, "the Court was divided ${ }^{25}$ Id. at 238. 
between a three-justice liberal bloc and a four-justice conservative bloc, with Hughberts (Hughes and Roberts) in the middle."26

The three-justice liberal bloc is one player, whom we shall call simply "the Left." The four-justice conservative bloc is another player, "the Right." The center justices, Chief Justice Hughes and Justice Roberts, are the third player, "Hughberts." It is not unreasonable to assume that a Chief Justice, confronted with a savage external political attack upon the Court as a whole, led by the most powerful politician of his day, would scek to minimize disagreement among the justices (in order to present a united front to the outside world), and at the same time to maximize his own power and leadership within the Court. We assume, therefore, that (I) the primary objective of Hughberts was to maximize unanimous decision-making by the Court; but if no common ground for agreement between the left and right blocs could be found, then, (2) Hughberts' secondary objective was to maximize his power by participating as often as possible in the minimal winning coalition. ${ }^{27}$

Since the game must have a "pay-off" that can be expressed in numerical terms, Schubert adopts the Shapley-Shubik empirical power index. "Simply stated," he says, "the Shapley-Shubik index measures the extent to which each justice shared in the power of decision, which is defined as the probability of his having been pivotal in the winning coalition." 28 After making the computations required, he is able to determine the strategy Hughberts should follow, which proves to be a "pure strategy."

I. If the Left and Right choose conflicting alternatives, Hughberts should always form a coalition with the Left, if possible.

II. If the Left and Right choose conflicting alternatives and Hughberts cannot form a coalition with the Left, then he should form a coalition with the Right.

III. If the Left and Right choose equivalent alternatives, Hughberts should always join them in a single grand coalition of all three players. ${ }^{29}$

Given Hughberts' purposes in the "game," this appears eminently sensible. If the other seven justices agree, Hughberts should agree, thus achieving the desired unanimity. If they disagree, making unanimity impossible no matter what he does, he should vote with the Left, since voting with the three-member Left gives Hughberts a larger pay-off in Shapley-Shubik terms (.40 as opposed to the mere .33 he would win if he played with the Right). ${ }^{30}$ As Schubert says, there is no contradiction between "minimizing the number of split decisions and maximizing participation in minimal winning coalitions"; 31 that is to say, there is a happy compatibility-

\footnotetext{
${ }^{28}$ Schubert, The Study of Judicial Decision-Making As An Aspect of Political Behavior, 52 Am. Pol. Scr. Rev. 1007, 1023 (x958).

${ }^{27}$ Giendon A. Schubert, Quantitative Analysis of Judicial Behavior 195-96 (1959).

${ }^{88}$ Schubert, The Study of Judicial Decision-Making As An Aspect of Political Behavior, 52 AM. Por. Scr. REv. 1007, r022 (1958). See Shapley \& Shubik, A Method for Evaluating the Distribution of Power in a Committee System, 48 AM. Poi.. Sci. Rev. 787 (1954).

${ }^{20}$ Glendon A. Schubert, Quantitative ANalysis of Judiciaz Behavior I99 (1959).

${ }^{80}$ Ibid.

s1 Id. at 196.
} 
too happy, in fact-between the two objectives that Schubert attributes to Hughberts in the game, or more precisely, in this version of the game.

But there is an earlier version of this game, published in the American Political Science Review, and in it Hughberts had three purposes, or objectives: he wanted as many unanimous decisions as possible and he wanted to maximize his own power, but he also wanted to direct "the Court to as liberal a course of decision as possible...."32 One cannot help wondering why Hughberts gave up this purpose in the later version of the game. The answer is not hard to find. If the three teams, Left, Right, and Hughberts, were always made up of the same number of members, Hughberts could form a permanent coalition with the Left, thus "directing the Court" in the liberal direction and, at the same time, scoring the most ShapleyShubik power points. But the blocs are "subject to occasional irregularities on the part of the individual justices [which] assume the form of non-participation and defection."33 There is some shifting among the players, or "splintering or nonparticipation," as Schubert puts it in the earlier version. ${ }^{34}$

We are now in a position to understand why Schubert chose to present this abstract version of the game in the later publication-that is, why he did not attribute to Hughberts any purpose having anything to do with the substance of the decisions. If there is "splintering or non-participation," Hughberts might be faced with the situation where the fulfillment of one purpose meant the sacrificing of another, which is a situation that judges and other political men face with some frequency when they are doing their work instead of playing games. An example of this situation is when Hughberts is faced with a four-member Left and a three-member Right. If he votes with the Left, he scores only .33 Shapley-Shubik power points; if he votes with the Right, he scores 40 points, but he has to sacrifice his concern with the substance of the decision. Schubert saves poor Hughberts from this terrible dilemma by changing the game (this time knowingly): all concern with the substance of the decision must be dropped. Hughberts must cease to be a justice of the Supreme Court and become a pure gamesman.

But even as pure gamesman Hughberts' troubles are not over. If one member of the Right bloc does not participate, Hughberts may be faced with a three-three split, and in such a case his Shapley-Shubik power index cannot tell him how to vote, since he would score the same number of points by voting with the Left or the Right.

\footnotetext{
${ }^{32}$ Schubert, The Study of Judicial Decision-Making As An Aspect of Political Behavior, 52 AM. PoL. Scr. Rev. I007, I022 (1958).

${ }^{33}$ Glendon A. Schubert, Quanttative Analysis of Judictal Behinor 200 (1959). It should be noted that while the other groups are subject to "splintering," apparently because like other human beings, their members experience "various kinds of personality disorders" (not, of course, because after a process of rational consideration, they decide to vote in a way contrary to their usual partners), the game does not permit Hughberts to split up.

${ }^{34}$ Schubert, The Study of Judicial Decision-Making As An Aspect of Political Behavior, 52 Am. PoL. SCI. REv. 1007, 1022 (1958).
} 
Schubert concludes the Hughberts game in the following paragraph: ${ }^{35}$

Whether the justices of the Supreme Court were playing a game during the 1936 Term, with power as the object, we cannot say. But we can say that their actual behavior was in exceptionally close correspondence to the way they should have behaved if they had been competing in such a game. To the extent that the model suggests interpretations that add to our understanding of the Court, and directs attention to relationships and data that would not be perceived from another perspective, we may be justified in concluding that game theory has something worthwhile to contribute to the study of public law.

But neither of his models, the two-objective version or the three-objective version, tells the student of public law any more than he already knew. The simple and familiar impression that Hughes and Roberts added their votes to those of Brandeis, Cardozo, and Stone, in order to forestall the packing of the Court, is in no way upset by Schubert's game analysis. We are still permitted to say that a "switch in time saved nine," meaning that it was the desire to save nine, and thereby the integrity of the Court, that led Hughes and Roberts to switch. Not only does Schubert's analysis not upset the familiar explanation, but it obscures what it purports to tell us. He says that whether "the liberals and the conservatives-or even Hughes and Roberts-were in fact playing for power as we have defined it is neither here nor there"; 30 but this is quite obviously not true. Schubert is entitled to disclaim proving that they were "playing for power," but the interpretation "suggested" by the model must surely be that the justices were in fact playing for power. To the extent that he alludes to other purposes (Hughes' concern for maintaining the integrity of the Court, and the concern for liberal decisions-later dropped when it made game playing awkward), he only engages in a crude version of the usual interpretation. That "Hughberts" picked up the maximum number of Shapley-Shubik points by switching is coincidental, or at most, merely an alternative explanation of "his" vote. But which explanation is more reasonable? Which of the preceding explanations is more compatible with Hughes's desire, in Schubert's own words, to protect the Court from "a savage external political attack . . . led by the most powerful politician of his day"? 37 In fact, Schubert knows that the justices do not "play for power."

Toward the beginning of his account of the games, he mentions the possibility that the justices might be guided by their ideas of justice, but he refuses to make such an assumption for the purposes of his game analysis. Why? In part because he thinks it "unreasonable and unrealistic," and in part because "it reflects our difficulty in relating the concept of justice to a linear numerical scale in such a way that it will possess the quality of unrestricted transferability (like money), as must be done for all utilities."38 But power, at least in Shapley-Shubik terms, can be measured, so

${ }^{35}$ Glendon A. Schubert, Quantitative Analysis of Judicial Behayior 210 (1959).

so Id. at 196. (Emphasis added.)

s7. Id. at 195 .

${ }^{39}$ Id. at 176. (Emphasis added.) 
"we shall assume that the utility which is the aim of the game for Supreme Court justices is POWER."39 But a few pages later he says that, ${ }^{40}$

the Supreme Court is a power group, with subgroups whose organization, motivation, and behavior are political ... [and by] "political," it is meant that members of the Court are divided on various issues of public policy; that the Court's decisions have a significant effect upon the making or reshaping of various aspects of public policy; and that there are "activists" within the group who consciously attempt to control the Court's decisionmaking.

The justices are concerned with the issues making up public policy, their decisions affect public policy, but since this concern cannot be related "to a linear numerical scale," in playing the game Schubert has to forget what he knows about the Court. His common sense, with which he is more than amply endowed, must give way to his behavioral non-sense-or, to be precise, to the limitations imposed by his methodology.

We conclude this lengthy, perhaps even tedious analysis of game theory applied to judicial behavior by pointing out that, once again, we have not evaluated it "within the limits of [our] own system of thought, within which, of course, it is corrupt and untenable." ${ }^{11}$ Like the authors of Essays on the Scientific Study of Politics, we have given reasons why it is so within the limits of the system of thought of others.

\section{II}

\section{Behavioral Science as Prediction}

Political Scientist S. Sidney Ulmer has also been drawn to the study of judicial behavior. His intention in one study is to discover "whether inferences about Supreme Court behavior . . . can be sharpened by a shift from the traditional method of analysis" to the new "quantitative" method." The focus of his attention is on the racial exclusion cases decided by the Court during the period, I935-1960. ${ }^{43}$

In cases where it has been alleged that Negroes have been discriminated against in the selection of jurors or jury lists, the Court has compared the proportion of Negroes on juries or jury lists with their proportion in the population from which jury lists are drawn up. The purpose of this comparison is to determine whether exclusion of Negroes is due to chance or is an intentional policy, and therefore a

${ }^{30}$ lbid.

${ }^{40}$ Id. at 2II. (Emphasis added.)

"1 Book Review, 27 AM. Soc. Rev. 702, 703 (1962). A final word on game theory. Let us assume for the purposes of the game that the contemporary Court has a first amendment case to decide. Let us also assume three "players": a three-member bloc that votes to uphold the constitutionality of the state censorship law, and a four-member bloc that votes to uphold the claim of a bookseller who has been convicted under the statute. The game is to determine the rational strategy available to the third player, "Doublack," or to predict how "Doublack" will vote.

${ }^{43}$ See Ulmer, Supreme. Court Behavior in Racial Exclusion Cases: 1935-1960, 56 Am. Por. Scr. Rev. 325 (1962).

${ }^{3}$ The cases extend from Norris v. Alabama, 294 U.S. 587 (1935), to Eubanks v. Louisiana, 356 U.S. 584 (1958). See list, Ulmer, supra note 42 , at 327 . 
violation of the fourteenth amendment. With statistics drawn from the cases themselves and with the use of a probability formula, UImer sets out to determine the "probability of the difference between RHP and RHS occurring by chance," with RHP representing the racial heterogeneity of the relevant population and RHS the racial heterogeneity of the sample, or jury or jury list. He states his conclusions, which rest on computations that need not be described here, in the form of hypotheses: ${ }^{45}$

(x) The total absence of Negroes from a state jury system or a part thereof is a violation of the fourteenth amendment given two conditions:

(a) The proportion of Negroes in the qualified population is substantial (i.e., 7.2 per cent or more).

(b) The period of exclusion is long (i.e., I6 years or more).

(2) Partial absence of Negroes from a state jury system or a part thereof is a violation of the fourteenth amendment given two conditions:

(a) The racial heterogeneity of a sample population (read jury or jury list) differs from that of a qualified population to an extent expected by chance less than five times in one hundred.

(b) The sample is sufficiently large (60 or more cases).

As he says, these are "explanations consonant with the data examined...." They are, furthermore, and this is the achievement of his mathematical analysis, "stated with sufficient precision to make empirical testing possible." ${ }^{\text {"6 }}$ Whether this is a significant achievement, or will, after empirical testing, lead to a significant achievement, can best be considered with reference to a similar, but more finished, study, a study made by Fred Kort.

Kort has succeeded in carrying this kind of analysis one step further, to the point where he successfully predicts a whole series of Supreme Court decisions in right-to-counsel cases. His study is "designed to demonstrate that, in at least one area of judicial review, it is possible to take some decided cases, to identify factual elements that influenced the decisions, to derive numerical values for these elements by using a formula, and then to predict correctly the decisions of the remaining cases in the area specified." His analysis, he goes on, is made "independently of what the Court said by way of reasoning," and relies solely on the factual elements stressed by the justices. His source group is a set of cases from Powell v. Alabama in 1932 to Foster $v$. Illinois in $1947^{48}$ From the opinions in these fourteen cases he derives twenty-six "pivotal factors," such as the youth of the defendant and whether

4 Ulmer, supra note 42 , at 327.

"2. Id. at 330 .

"Ibid.

${ }^{47}$ Kort, Predicting Supreme Court Decisions Mathematically: A Quantitative Analysis of the "Right to Counsel" Cases, 5I AM. Poz. Scr. REv. I (1957). For a study similar to those of Kort, Schubert, and Ulmer, see Tanenhaus, Supreme Court Attitudes Toward Federal Administrative Agencies, 22 J. PoLITICS 502 (1960).

${ }^{48}$ See list, in Kort, supra note 47 , at 5. 
he was advised of his right to counsel, and assigns to each factor a weighted numerical value. Added together for a particular case, these constitute what he calls a "composite value," with which he then examines the cases in the source group to find the breaking point. His conclusion is that any "composite value equal to or higher than $389 . I$ will indicate a decision in favor of the petitioner; any composite value equal to or lower than 370.4 will indicate a decision against the petitioner." ${ }^{\prime 9}$ To test this prediction, he computes the composite values of each case in a series decided from 1947 to 1956 , and finds that the prediction is borne out in every one. Thus, he asserts, "quantitative analysis discloses a consistency of Court action concealed in conventional qualitative interpretation."

It would be quibbling to insist that Kort has not by any means succeeded in excising every element of "qualitative interpretation" from his quantitative analysis; but it is at least worth mentioning that three of this writer's graduate students at Cornell, each thoroughly familiar with judicial materials, could not agree on the pivotal factors present in a recent case, Hudson $v$. North Carolina, ${ }^{51}$ which is sufficient to demonstrate the obvious, namely, that the identification of these factors is by no means automatic. It is also worth a mention (but no more than a mention) that all three graduate students came up with a "composite value" lower than the minimum needed to insure a decision for the defendant petitioner, but that nevertheless the Court decided for the defendant petitioner. ${ }^{52}$

Nor is it our purpose to question the soundness of Kort's mathematics. This has been done by mathematician Franklin M. Fisher, who also emphasized that the circumstances that permit prediction are those under which no new factors appear.53 Fisher's point may be made as follows: the scientific method requires that the experiment lend itself to replication, so as to permit testing of the findings made during the first experiment. But Kort cannot assist, or provide the data for, this replication in new cases, involving new and as yet unweighted and unweightable factors. "Other cases cannot be predicted with any assurance, since we can never be sure that a factor, concerning whose weight we have no information, will not be important enough to alter the decision." ${ }^{44}$ Kort, in reply, at first conceded the possibility of new factors "for which no weight has been obtained from previous cases," but ended by discounting the importance of this, because, he said, eventually the analyst will have "a large sample of cases" that will contain "virtually all important factors that are likely to occur." "T5 The case for prediction rests on the elimination of chance.

${ }^{10}$ Id. at 10.

${ }^{\circ} \mathrm{Id}$. at $\mathrm{II}$.

${ }^{81}{ }_{3}$ U.S. 697 ( 1960 ).

E2 The three composite values were $273.6,3$ r9.r, and 338.2 .

${ }^{83}$ Fisher, The Mathematical Analysis of Supreme Court Decisions: The Use and Abuse of Quantitative Methods, 52 AM. Poz. Scr. Rev. 32x, 338 (1958).

ot Ibid.

${ }^{65}$ Kort, Reply to Fisher's Mathematical Analysis of Supreme Court Decisions, 52 AM. PoL. Scr. Rev. 339, 348 (I958). 
It also rests, as Fisher points out at the end of his article, on the elimination of development in the law: $:^{58}$

Mathematics can perfectly predict on the basis of the presence or absence of factors in a case only in those areas where the law has attained a settled state and where public policy and opinion are such as to require that it remain settled. These are the frozen areas of easy prediction, however, so that mathematics can add only to the power to analyze, not to the power to predict. In other, more complicated, more interesting, and more inherently important areas where the law is still developing or where public policy requires that it should continue to develop, mathematical analysis provides no substitute for the opinions of the Court. Law, even mathematical law, is made by men.

The statement serves to remind us of the obvious inadequacy of quantitative analysis of judicial materials. Even if we were to concede that the methodological obstacles could be overcome, of what use is this quantitative analysis and to whom is it useful? Ulmer, in his article on the racial exclusion cases, says it will be of use to lawyers and to political scientists specializing in public law, although he does not explain why this should be so in the latter case..$^{57}$

A judgment as to discrimination is a rebuttable inference from a particular combination of numerically expressed facts or factual relationships. The lawyer, by necessity, must be interested in identifying the criteria which guide the formulation of such a judgment. The political scientist specializing in public law may equally have an interest if he would explain the Court's actions.

There is no reason to doubt that lawyers with clients to advise must, "by necessity," be interested in the identification of the factors on which decisions hinge. They are paid to do this. Yet, there is serious doubt that Ulmer's conclusions will add to what the lawyer already knows in general and, in those borderline cases where, conceivably, the lawyer might be assisted by Ulmer's conclusions, whether those conclusions will hold up. Might a difference between RHP and RHS "to an extent expected by chance less than" four (instead of five) times in a hundred be sufficient for the Court to find a violation of the fourteenth amendment? Ulmer cannot be any more certain of the answer than the practicing attorney, who, incidentally, is likely to seek an appeal in all borderline cases with or without the benefit of Ulmer's numbers.

But what of the legal scholar or political scientist? Even assuming that the use of mathematical analysis can identify the decisive factors in a case with more precision than "conventional qualitative analysis," it is emphatically not true that the legal scholar's work has been thought to culminate in an identification of the factors in a case or, as Schubert would have it, in an answer to the question, "What decisions has the Supreme Court made?" This is certainly not true of the best articles or even the vast majority of the articles in legal journals today, and, if the Association of

\footnotetext{
ss Fisher, supra note 53, at 338 . Among other things, this can also be said of Paul C. Bartholomew's attempt to show that computers can decide cases. See Bartholomew, The Supreme Court and Modern Objectivity, 33 N.X. STate Bar J. 157 (196r).

${ }^{87}$ Ulmer, silpra note 42 , at 325 .
} 
American Law Schools can be accepted as qualified to judge, it is emphatically not true of the best studies written in the past. Of the hundreds of articles collected in the four massive volumes of the Selected Essays on Constitutional Law, ${ }^{58}$ written by such distinguished legal scholars as Edward S. Corwin, Robert E. Cushman, and Thomas Reed Powell, to name only three of many, it is doubtful whether a single one undertakes to do no more than to answer the question of what decisions the Supreme Court has made or even to explain judicial behavior. Their explanations, or explications, of decisions necessarily implied or led to praise or blame of judicial behavior. ${ }^{59}$ If the new behavioral study of law promises merely to "identify the factors" in a case, but to do so more precisely than was done in the past, it will be doing what scholars in the past regarded as only the first step in their work.

Originally, a political scientist was understood as the teacher of those who give laws to a particular community, just as a jurist was understood as the teacher of judges and lawyers, those whose daily work is in and with the law. Both political science, or political philosophy, and jurisprudence were concerned with the questions that arise in political life: in constitutional conventions, legislative assemblies, cabinets, court rooms, or in the lobby outside the office of the Governor of Mississippi. Such questions arise out of conflicts between men making up the political community, and governing that community consists, in part, in making and applying the rules by which these conflicts are settled or resolved. Since each party to the conflicts usually asserts that what he is contending for is not only good for him but good for the community as a whole as well, the legislator and judge must resolve the conflict in terms of what they regard as good for the community as a whole; in short, they must be guided by the question of the common good. (There is no difference in principle between the role of Lawgiver, or framer of constitution, and legislator or judge; the latter two merely work within the framework of an already defined public good, one defined with greater or lesser specificity.) But the question of what is good for the men of that particular political community cannot be isolated from the question of what is good for man simply, or, what is good by nature. Thus, consideration of the problems arising in political life point to the question of the best possible political order or the best possible laws: all political decisions, whether by the framers of constitutions, legislators, administrators, judges, or masters in chancery, are based, consciously or unconsciously, on a view of what is good for man. The political philosopher claimed to possess this knowledge and therefore claimed to be the teacher of those for whom this knowledge was relevant. ${ }^{60}$ His science (scientia: knowledge) was knowledge of what is good for man. The

\footnotetext{
${ }^{58}$ Ass'v of American Law Schools, Selected Essays on Constitutional Law (4 vols. i938).

${ }^{80}$ As examples that come quickly to mind, see Thomas Reed Powell, The Child Labor Law, the Tenth Ametndment, and the Commerce Clause, in 3 Selected Essays on Constimutronat Law 314 (1938), reprinted from 3 Southern L.Q. 175 (x918); and a recent article, Goldstein, The State and the Accused: Balance of Advantage in Criminal Procedure, 69 Y YLE L.J. II 49 (1960).

"O Strauss, On Classical Political Philosophy, 12 Socinz ResEARCH I0O f. (1945). This study is reprinted in Leo Strauss, What is Polstical Phisosophy?, 78-94 (1959).
} 
numerous references to Montesquieu in the Federalist Papers, to Plato, Aristotle and Cicero in other writings of the framers of our Constitution, ${ }^{01}$ as well as the Lockian language adopted by Jefferson in the Declaration of Independence, all attest to the extent to which political philosophers were accepted as teachers by the men who brought this country into being. The Corwins, Cushmans, Freunds, Walton Hamiltons, Powells, and Thayers, to mention only those men whose work appears in the Selected Essays on Constitutional Law, continued the work of their illustrious predecessors, continued it on a less exalted level, surely, but on a level that most of us can only aspire to attain.

Behavioral science denies the very possibility of knowledge of what is good for man and, necessarily therefore, denies the possibility of an objective common good. ${ }^{.2}$ It therefore denies the very premise on which the old-fashioned political and legal science was built. Yet, despite this denial, which amounts to a denial of the possibility of science in the original sense, there are more men today claiming the title of political scientist than ever before in the history of this old discipline.

The explanation of this seeming anomaly lies in the redefinition of science. The new science eschews all interest in the best political order or in the best laws, and confines itself to acquiring information as to the way men behave. To justify its claim as a science, as opposed to a form of journalism or social recording, it adopts the "scientific method," involving itself in mathematics, hypotheses, models, developmental constructs, predictions, and the like, modeling itself on what is probably regarded as the queen of the sciences today, physics. And just as physics culminates in a body of laws describing the physical universe, behavioral science would culminate in a body of laws describing the social universe. The science of man will be a science of human behavior. ${ }^{63}$ Behavioral science is a science because its methods are "scientific," because they are "similar to those of the natural sciences," and because it limits its inquiry to what can be verified empirically. ${ }^{65}$ Since the goodness of a law or a constitution cannot be verified empirically, which means that its goodness cannot be seen or touched by one of the senses, ${ }^{66}$ questions of the goodness of laws are of no concern to these new scientists as scientists. The social scientist "cannot be an advocate in his role as scientist."

Nevertheless, a major part of the work done by behavioral scientists in the law

ol See, for example, John Adans, A Defence of the Constitutions of Governasent of the United States of AMERica passim (I794).

${ }^{62}$ Dahl, Political Theory: Truth and Consequences, II Worsd Politics 91 (1958).

${ }^{\text {o3 }}$ Kirkpatrick, The Impact of the Behavioral Approach on Traditional Political Science, in Austix Ranney (Ed.), Essays on the Behavioral Study of Politics 1, 25 (1962).

os Truman, The Impact on Political Science of the Revolution in the Behavioral Sciences, in RusEARcH Frontiers in Politics and Government: Brookings Lectures, 1955, at 203.

${ }^{65}$ The social sciences are "those theoretical disciplines which seck to understand and predict human behavior in terms of general principles empirically tested." Rose, The Social Scientist as an Expert Witness, 40 Minv. L. REv. 205, 206 (1956).

${ }^{60}$ Berns, The Behavioral Sciences and the Study of Political Things, 55 Am. Pou. Scr. Rev. 557-58 (196r).

${ }^{67}$ Rose, supra note 65 , at 215 . 
assumes a knowledge of what is good for man. Strange as this may be from their point of view, it is not unexpected, for there is something in the materials of the law that points even this new breed of legal scholar, as it has always pointed legal scholars in the past, to the question of the goodness of the laws.

\section{III}

\section{Behavioral Science and Expert Testimony}

Some fifteen years ago Learned Hand wrote an opinion in a second circuit case that produced a flurry of interest among behavioral scientists. The case involved a government appeal from a district court order granting naturalization to a man who had, within the five year period during which, according to the statute, ${ }^{68}$ he was required to have been of "good moral character," chloroformed his thirteen year old deformed son. For this he had been convicted of second degree murder but was placed on probation, the jury having recommended "utmost clemency." Judge Hand in his opinion for the court said that the statutory standard, good moral character, was to be ascertained by determining whether "the moral feelings, now prevalent in this country," would be "outraged" by the conduct in question. ${ }^{60}$ Instead of conducting an opinion survey, he decided the case by judging, or guessing, that the public would not approve of such conduct; but his statement of the rule proved, for more than one social scientist, to be a clarion call for assistance. For, what better way to determine prevailing "moral feelings" than by a public opinion survey? Hand's opinion was followed quickly by a research project described in the article, "Ascertaining the Moral Sense of the Community,"70 and later by another article dealing with the whole question of social science testimony. ${ }^{71}$ In this latter article, the author, Jack Greenberg, quotes from the opinion of the court in Parmelee v. United States, in which Judge Miller said he looked forward to the day "when social scientists can advise not only courts, but the people generally; just as physicians ... do today."72

This was said in 1940 ; by 1956 , according to Greenberg, the day had arrived when social science was ready to assume this extremely responsible task. In fact, according to a member of the legal profession, this task had already been performed: "When the final decision was handed down in the public school segregation cases, it rested not on conceptual legal principles or the legislative history of the fourteenth amendment . . . but on the psychological finding of thwarted intellectual development."73

${ }^{68}$ Nationality Act of $1940, \$ 307$ (a)(3), 54 Stat. II42, 8 U.S.C. $\$ 707(a)$ (3) (I940), now covered by 66 Stat. 243 (1952), 8 U.S.C. $\$ 1427$ (a)(3) (1958).

"Repouille v. United States, I65 F.2d I52, I53 (2d Cir. I947).

${ }^{70}$ Cohen, Robson \& Bates, Ascertaining the Moral Sense of the Community: A Preliminary Report on an Experiment in Interdisciplinary Research, 8 J. LEGAL ED. 137 (1955).

${ }^{11}$ Greenberg, Social Scientists Take the Stand: A Review and Appraisal of Their Testimony in Litigation, 54 Mrch. L. REV. 953 (1956).

"ia Parmelee v. United States, I13 F.2d 729, 737 (D.C. Cir. 1940).

${ }^{73}$ Will Maslow, "The Uses of Law in the Struggle for Equality," address, Atlantic City, N.J., December, 1954, as quoted in Cahn, Jutrisprudence (American Survey), 30 N.Y.U.L. REv. 150, 157 n.I6 (1955). 
There is no doubt that the school segregation cases, and the role played-or allegedly played ${ }^{74}$-by social scientists in those cases, stimulated a greater interest in the law among social scientists than any other case; and for this reason, as well as another, it provides the most appropriate context in which to discuss the contribution that behavioral or social science can make in the law. The question to be considered is this: what is the relation of a social science that is neutral on the question of justice to a constitution designed by its framers "in order . . . to establish justice"?

In the most celebrated study of the Negro problem in America, Gunnar Myrdal testifies to the inability of social scientists to deal with questions of justice or to make policy judgments: ${ }^{75}$

We all claim that our factual or theoretical studies alone cannot logically lead to a practical recommendation. A practical or valuational conclusion can be derived only when there is at least one valuation among the premises.

And, according to Myrdal again, "valuations ... cannot be judged by such objective standards as science provides."76

If these scientists cannot make practical recommendations, their role in the judicial process must be limited to the performance of a subordinate function, perhaps that of collecting information on the basis of which the judges might then draw the practical or legal conclusions. This, or something similar to this, is the role advocated by Arnold M. Rose:77

What the social scientist can do in the courtroom is to present certain social facts that serve as conditions affecting the outcome of the case. That is, there are certain cases in which the judge must assume certain social facts to be true before he can. arrive at any decision.

In view of their confessed lack of competence to pronounce upon policy or value judgments, it is difficult to understand the role of thirty-two of their number, most of them psychologists and social psychologists, who signed the statement printed as the appendix to the appellants' brief in the school segregation cases. In the preface to this appendix, they acknowledge the presence of "moral and legal issues ... with respect to which [they] cannot speak with any special authority and which must be taken into account in the solution of the problem."78 Their concern, they say, is solely with the "factual issues involved," the effect of compulsory segregation. Their conclusion as to this effect is that "enforced segregation is psychologically detrimental to the members of the segregated group."ro In short, they claimed to

"Cahn, The Lawyer, the Social Psychiatrist, and the Truth, 31 N.Y.U.L. REv, 182 (1956).

20 Gunnar Myrdal, An American Dilemma 1052 (I944).

${ }^{30} \mathrm{Td}$. at ro27.

${ }^{77}$ Rose, supra note 65 , at 215 . If we look back to the origin of the practice of introducing nonlegal cvidence in constitutional cases, to, that is, the Brandeis brief, we find confirmation of this vicw of the social scientist's role. See Paul A. Freund, ON Understanding the Suprexe Court 88 (195I).

${ }^{78}$ United States Supreme Court Briefs and Records, Brown v. Board of Education, 347 U.S. 483 (1954), appendix to Appellants' Brief, pp. 1-2.

id. at ro. 
have testified to the damage wrought by the policy and to have left the legal and moral issue for the courts to decide; but their testimony is not quite so innocent of evaluation as they suggest. For, to discern damage or detriment to the psyche, as these thirty-two scientists claim to have done, requires knowledge of a well-ordered psyche, or, as it used to be referred to, a well-ordered soul. Without a knowledge of health, there can be no recognition of disease.

Despite the customary disavowal of any concern with what they call the moral issue in law, these psychologically oriented social scientists deserve a measure of praise, for, unlike Schubert, Ulmer, and Kort, they at least see the relevance of the question of what is good for man. What is surprising is not that psychologists should raise the question (for what sort of a scientist is it who is content to be an errand boy for judges?), but rather the manner in which they discuss a question that is absolutely central to their science, or the extent to which they neglect to discuss the question while seeing its relevance. That social scientists are not yet qualified to make the kind of judgment implied in this statement in the public school segregation cases, and that the task facing social scientists is precisely to prepare themselves to make that kind of judgment, is acknowledged by Philip Selznick, a California sociologist with a national reputation. According to Selznick, the sociologist must transcend the role of mere "technician or engineer," and prepare himself for one of "true intellectual autonomy and maturity" in which he would address "himself to the larger objectives and guiding principles of the particular human enterprise he has selected to study." 80 For the sociologist of law, this will require a disaffection with legal realism, for the legal standard cannot be the standard of actual behavior, however "congenial [this is] to a sociological orientation." 'To do this, the sociologist of law will have to seek the knowledge traditionally sought by the political philosopher; he must aspire to knowledge of what is good for man. ${ }^{81}$

The idea of reason presumes that there are principles of criticism of positive law.... We must go on to seek out the foundations in reason for choosing among human norms those that are to be given the sanction of law. This will bring us, I cannot doubt, to an acceptance of some version of a doctrine of natural law, although it may not, and perhaps should not, be called that, given its historical associations. .. . But whatever the philosophical auspices, the search for principles of criticism based on social naturalism must go on. Law based on reason and nature summons man to his potentialities but sees those potentialities as something that science can identify; law based on reason and nature locates the weaknesses of the human spirit, such as pride, apathy, and self-abasement, and works to offset them.

But what resources are available to the social scientist that qualify him for this exalted role? Which of the social science disciplines is most likely to possess, or to have access to, the resources, now that all of them have based themselves on the so-called separation of facts and values and declared their incompetence to speak on

\footnotetext{
so Selznick, The Sociology of Law, I2 J. LEGAI Ed. 52I, 522 (1960).
}

${ }^{8 x}$ Id. at 531 . 
the question of what is good for man?82 The answer is probably psychology-at least, the question is most likely to assert itself there. As Lon Fuller said a few years ago in the context of a discussion of psychology and modern jurisprudence, ${ }^{83}$ psychoanalysis

assumes that the purpose-forming system called a man may be in need of being "straightened out," and at the same time contains within itself the sign posts that will direct the straightening-out process ... [and if] the psychoanalyst does not do something roughly equivalent to helping his patient realize his "true nature" then his whole profession loses intelligible meaning.

Unfortunately, the psychologists' understanding of what is involved in their enterprise, to say nothing of their prescriptions, is hopelessly inadequate.

In Lewis Feuer's treatment, the question of what is good for man is central, but the human psyche disappears altogether. He begins promisingly enough by asserting that the task of social science is "to help construct an order in which rational values are actualized throughout society," but it turns out that the "values" he wants actualized are those that "are expressive of the primal drives of the organism," those that "promote the maximal satisfaction of the underlying biological drives. . . ."84 Thus, psychology might be said to disappear into a crude biology, and an oldfashioned reader, like Glaucon in Plato's Republic, will wonder whether this is not a prescription for a city of pigs instead of men.

Erich Fromm avoids Feuer's crudities, but his analysis and prescriptions are equally inadequate. He says that "what is good or bad for man is not a metaphysical question, but an empirical one that can be answered on the basis of an analysis of man's nature and the effect which certain conditions have on him." This analysis discloses that men "are born equal but they are also born different," because of the difference in "inherited equipment, physiological and mental. ..." "The genuine growth of the self is always a growth on this particular basis; it is an organic growth, the unfolding of a nucleus that is peculiar for this one person and only for him." It is the job of society to promote a "culture" whose aim and purpose is the "growth and happiness" of the individual; a culture in which the individual's "conscience and ideals are not the internalization of external demands, but are really his and express the aims that result from the peculiarity of his self."

Does this mean that all "selfs" should be fostered or encouraged to grow? Fromm says "there is no higher power than this unique individual self ... [and] that the growth and realization of man's individuality is an end that can never be subordinated to purposes which are supposed to have greater dignity." Is Fromm not aware that some "selfs" have a tendency to grow into ugly things? He is. The fact that "man should not be subject to anything higher than himself," he says, "does not deny the dignity of ideals," and there is a "difference between genuine and fictitious

\footnotetext{
${ }^{89}$ MYRDAL, op. cit. supra note 75.

${ }^{80}$ Fuller, American Legal Philosophy at Mid-Century, 6 J. Legal ED. 457, 473 (I954).

“Letwis Sayuez Feuer, Psychonvalysis and Enitcs 6, 13, 120 (1955).
} 
ideals. ..." What are genuine ideals? Those that "express the desire for something which is not yet accomplished but which is desirable for the purposes of the growth and happiness of the individual." But each self is different, we were told, and its growth is like the "unfolding of a nucleus that is peculiar for this one person and only for him." So the question persists: what is a genuine ideal? And the answer persists:

We thus come to define a genuine idea as any aim which furthers the growth, freedom, and happiness of the self, and to define as fictitious ideals those compulsive and irrational aims which subjectively are attractive experiences (like the drive for submission), but which actually are harmful to life.

Or, "if man can realize his self fully and uncompromisingly, the fundamental cause for his asocial drives will have disappeared and only a sick and abnormal individual will be dangerous." But if every self is different, where is the norm that allows us to identify the "abnormal"? Fromm's argument turns back on itself continually, never escaping from the very small circle of its empty formalism. The same thing is repeated again and again: "realization of the self," the "utmost affirmation of the self," the "spontaneous activity of the total, integrated personality," but we end where we began, with no knowledge of what it means in fact. Fromm talks continually of growth without having any conception of a fully grown personality, or, to refer back to Lon Fuller, of man's "true nature." Something fully grown implies an end, a telos; that is, it is a teleological idea, and that smacks of metaphysics, and Fromm has banished metaphysics from his system.

In his prize-winning book, The Structure of Freedom, behavioral scientist Christian Bay adopts Fromm's concept of the integrated personality, even though he has to admit that the "task of making empirical sense out of the concept . . . is still ahead," and, moreover, "it is no easy task."\$6 Bay makes "empirical sense" of the concept by doing explicitly what Fromm does implicitly, namely, by accepting the telos, or the idea of a fully grown man, from his own society. The substantive definition that science cannot provide is provided by the customs of the place. The "fundamentally integrated personality" for Bay is one "in which a successful solution has been found in the conflict between biological drive and social conscience. . . .87 If as Kluckhohn, Murray, and Schneider say in their widely-read book, "some psychologists have fought shy of the concept of function [because] it is teleological ... and, so, raises from its grave the horrific image of final causes and of supernatural design," $\$ 8$ what alternative is there to accepting without question the idea of

\footnotetext{
${ }^{85}$ ERICH Froms, ESCAPE FROM FREEDOM 266, 262-63, 270-7I, 265, 266, 267, 269, 258 (I94I). (Emphasis added.)

${ }^{80}$ Christian Bay, The Structure of Freedom 85 (1958).

${ }^{87} \mathrm{Id}$. at 86 .

${ }^{88}$ Clype Kluckhohn, Henry A. Murray \& David M. Schneider, Personality in Nature, Society AND CULTURE 34 (1954). They speak of function without, they say, referring to "final causes," by accepting the concept of need, drive, or vectorial force. This "avoids final causes because it points to an existing state of tension... within the organism as the action-initiating state." Id. at 35 . Need for what? Drive toward what? And what is a resolution of the tension?
} 
a "healthy personality" or a fully grown man, or "true nature" to be found in the customs of the place? Gordon Allport, another well-known modern psychologist, admits this forthrightly. Arguing that the psychologist qua psychologist cannot prescribe how a child should be raised, he says that the most he can do is to analyze man as he is, and then, "after a moral code has been chosen, find out means of incentive and training that will achieve the end desired." 89 Franz Alexander provides the same solution to the same problem when he defines the healthy or mature personality as one ruled by an ego whose efficiency is measured by the extent to which it succeeds in adjusting conflicting desires to the environment. ${ }^{30}$

All these psychologists reject the legitimacy or meaningfulness of the philosophic inquiry into what is good for man, and yet all of them are led inevitably to confront the question and to provide some sort of an answer to it. But, to say nothing further about its vacuity, or as Bay would say, the difficulty of making "empirical sense" out of it, the "healthy personality," or the "integrated personality," or the efficiently ego-governed personality is a flaccid substitute for the well-ordered soul. Every element of human excellence has been defined out of the concept, yet each of these modern psychologists is aware that his science requires something equivalent to human excellence. Philip Selznick knows it too, and he deserves praise for acknowledging it forthrightly. ${ }^{91}$

Thus, however much one might sympathize with the use to which social psychological evidence was put in the public school segregation cases, fidelity to the Constitution dictates extreme caution in the use of this evidence in a court of law. The Constitution was intended to "establish Justice," and one's conception of justice is necessarily related to one's conception of what is proper to man's nature. The Constitution was not ordained and established by "adjusters"; it was defended at the time of its greatest trial not by a conformer, a seeker of the easy way, but by Abraham Lincoln. Any psychology that cannot distinguish between the nobility of a Lincoln ${ }^{22}$ and the ignobility of a well-adjusted nonentity, any psychology that does not despise people whose horizon is limited to the consumption of food to satisfy the hunger drive, the seduction of women to satisfy the sex drive, or the reduction of psychic tension, is scarcely qualified to speak of the human condition, and its prescriptions, therefore, deserves but a limited standing in the courts of the land.

IV

\section{Behavioral Science as Polmical Philosophy}

The thirty-two social scientists in the school segregation cases are not to be criticized for modestly providing the Court with information respecting the effect of compulsory school segregation; it is only when the grounds of this information

${ }^{80}$ Gordon W. Aliport, Personrlity: A Psychological, Interpretation 52 (I937).

${ }^{\circ 0}$ Franz Alexander, Fundauentais of Psychoanalysis 203 (1948).

${ }^{91}$ Selznick, supre note 80 , at 53 I.

"Tharry V. Jaffa, Crists of the House Divided (I959). 
are examined and its theoretical implications seen, and when the social scientists generally are excited at the prospect of playing a new role in the law, that it becomes necessary to enter a word of caution. These thirty-two may state their purpose modestly, but Feuer and Fromm want to reorganize society; Myrdal may disclaim any policy role for his science as science, but Harold Lasswell has in mind the establishment of what one of his critics has called a "psychoanalytocracy"-that is, rule by psychoanalysts. ${ }^{93}$

If men are certain that they know the cure for the ills of society, they are likely to become impatient with traditional legal principles and procedures which have always been thought important precisely because of the great difficulty in knowing what is good for man, and what is good for man here and now. This does not mean that this knowledge is unattainable in principle, but only that, originally, it was thought to be within the competence of only a few exceptional persons to achieve it, and that these persons did not seek political power. ${ }^{94}$

The school segregation case was not the first occasion on which social scientists had testified in a constitutional case coming from the state of Virginia. More than a quarter of a century earlier Virginia had gone to the Supreme Court with a statute requiring compulsory sterilization of all mentally defective inmates of state institutions. ${ }^{95}$ The social scientists involved in the sterilization movement (and it was a national movement) were convinced that human inheritance was governed by Mendel's findings regarding pea plants-one of Virginia's expert witnesses had proved this to his own satisfaction by his studies of the Jukes family. The case, which culminated in Justice Holmes' famous epigram, "three generations of imbeciles are enough," was a feigned suit, initiated at the request of the eugenicists in order to win constitutional blessing for their program. This they accomplished, even though their so-called science was wholly unfounded. The petitioner-inmate had no friends and no objection to the operation, and probably no awareness of what was going on. The defense of her interests fell to her courtappointed counsel, but he had himself been a member of the governing board of the institution he was nominally defending her against, and he was a close friend of its superintendent, the man who had issued the sterilization order that began the case. The case was a farce. The Supreme Court's opinion was written by Justice Holmes, and Holmes, like the eugenicists, believed that "wholesale social regeneration . . . cannot be affected appreciably by tinkering with the institution of property, but only by taking in hand life and trying to build a race."96 The eugenicists wanted this and something that Holmes would not have wanted.

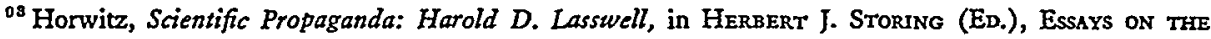
Scientific StUdY of Politics 299 (rg62).

oc Leo Strauss, De La Tyrannie 313 ff. (1954). An English translation of this work will be published in the near future. The essay in which the relevant discussion appears, Restatement on Xenophon's Hieto, is printed in Leo Strauss, What is Political Philosophy 112 (I959).

${ }^{\circ 5}$ Buck v. Bell, 274 U.S. 200 (I927).

${ }^{\circ}$ Holmes, Ideals and Doubts, xo ILL. L. REV. I, 3 (1915).
} 
One of Virginia's "expert" witnesses had plans to sterilize hundreds of thousands of Americans annually. As co-editor of the Eugenical News, he reprinted an entire speech by Dr. Frick, Reichsminister of the Interior, entitled "German Population and Race Politics." An editorial in the same journal stated openly that one "may condemn the Nazi policy generally, but specifically it remained for Germany in 1933 to lead the great nations of the world in recognition of the biological foundations of national character." One of his associates regretted that "the anti-Nazi propaganda with which all countries have been flooded has gone far to obscure the correct understanding and the great importance of the German racial policy. ..." Praise of the Nazi racial policy continued even as they pressed their "model" sterilization law on state after state, until the number of states with such statutes had grown from the twenty-one at the time of the Virginia case to twenty-seven a decade later. ${ }^{97}$ Perhaps the day will come when, as Judge Miller said in the Parmelee case, "social scientists can advise not only courts, but the people generally; just as physicians ... do today, ${ }^{, 98}$ but Buck $v$. Bell illustrates the hazards potentially involved and as well the failure of the courts to scrutinize a program cast in the language of science. This was science polluted by a vicious brand of politics, but when science asserts itself in the law, there is always the danger, and the strong possibility, that it will become irresponsible.

Certainly moderation does not characterize the principal work of scientific jurisprudence in our day, Frederick K. Beutel's Experimental Jurisprudence.00 If Beutel is to be believed, we are on the threshold of a solution to man's most fundamental problems; all that is required is the transfer of "the techniques and knowledge so successfully developed in the physical sciences ... into the field of social control...."100 His book is to be understood as a defense and an illustration of such transfer. It is with his defense that we shall be primarily concerned.

Man, he says, has achieved power over nature but not over himself; the "philosophy of social control" has not kept pace with "the revolutionary developments of physical science," which has engendered grave "mental, political and social maladjustments." This disproportion is largely the responsibility of "obsolescent practices," a reliance "upon ancient theories, institutions and dogmas about the nature of man fomented by clerics and philosophers [such as] the Bible, Aristotle, Plato, Adam Smith, Rousseau, Kant, Hegel, Montesquieu, Bentham, Blackstone and Marx."101 One such theory, or "fomented" theory, is the idea that man is not a part of nature in the same way that animals and inanimate objects are. "Most advanced thinkers [however] have now come to the conclusion that man in his most intricate

${ }^{87}$ For documentation, see Berns, Buck v. Bell: Due Process of Law?, 6 WEstern Pot, Q. 762 (1953).

${ }^{98}$ Parmelee v. United States, I13 F.2d 729, 737 (D.C. Cir. 1940).

${ }^{\circ P}$ Frederick K. Beuter, Some Potentjazities of Experimental Jurjsprudence as a New Branch of Sociar Science (1957).

${ }^{100}$ Id. at 4 .

${ }^{101} \mathrm{Id}$. at $\mathrm{II}$. 
aspects is as much a part of the universe as is an animal or a stone...."102 Being wholly in and of nature, man is as controllable as other animals and matter, and the means of effecting this control is experimental jurisprudence. "Nobody should be prepared to argue that the solution of all moral, social and international problems is presently possible by the technique of Experimental Jurisprudence, but can it not be said that it is foreseeable that the ultimate projection of procedures here suggested may lead to a possible means of resolution of clashes of opinion which in the past have been settled by brute force?"103

But what form will this resolution take? For, while we know that some thinkers in the past have argued that knowledge of the right way of life is accessible to unassisted human reason, and that, therefore, on the highest level there will be no "clashes of opinion," these same thinkers did not think that this knowledge is within the reach of everyone; and they did not foresee the time when the opinions that divide men and nations could be reconciled and differences dissolved. How, then, can the "technique of Experimental Jurisprudence" resolve them? Beutel says that when "law as a matter of regular practice enters the field of thought control, as is already the case in some totalitarian states, then the findings of the psychologists as to the working of the mind in reaching subjective choices will be of great use to the jurists."104 While suggestive, to say nothing more, this statement does not tell us all we want to know about this aspect of experimental jurisprudence; fortunately it is not all Beutel tells us. ${ }^{\text {I05 }}$

Looking far into the future, it may be predicted that the methods of legally directed thought control may eventually take over the direction and control of what some now call human values and that this power may be turned to scientific purposes. If this is to be accomplished, it should be along the lines of Experimental Jurisprudence. When this is done, there will no longer be any basis for the belief that social science is impossible because it contains no elements of control such as those found in physical sciences. The means of social control by law are now developing and increasing all about us. Mankind may soon be required to make the choice whether these powers are to be exercised for greed, lust and caprice of individuals or are to be used in the scientific advancement of the race.

Beutel is not altogether clear as to what he means by the "scientific advancement of the race," and the laws appropriate to this advancement; but he does have a test, of sorts, of good laws. ${ }^{100}$

The laws to be enacted or recommended should be those which lead to the greatest sum total of satisfaction of needs, demands and desires, in that order of rank. Thus a more complicated person is certain to have greater wants than a simple individual, and his combined interests as a whole will therefore weigh heavier in the scientific scale than those of a less complicated (less intelligent, if you will) individual.

${ }^{200}$ Id. at 9 .

${ }^{108}$ Id. at 36 .

${ }^{106} \mathrm{Id}$. at 40.

${ }^{100}$ Id. at 51.

${ }^{100} \mathrm{Id}$, at 54 
But supposing the "less complicated" people object to this dispensation?

If . . . sufficient public interest is to be developed in adopting new scientific methods, it will be necessary for this small [at most "six percent of the entire population"] nucleus from which come the able scientists to convince the great majority to agree to types of governmental and legal devices which the overwhelming mass of people cannot even understand. Under the circumstances, the development of popular pressure for adoption of scientific discoveries into the legal and governmental field sufficient to overcome the inertia of those in control of the machinery is difficult, if not impossible, to achievc. ${ }^{107}$

That the scientists should be restrained by the need to get the consent of the ("less complicated") governed is reassuring, but perhaps only temporarily, since we know that this restraint does not derive from any principle to be found in the book. The Declaration of Independence states that governments derive "their just powers from the consent of the governed," but Beutel dismisses its "theories" as mere "fictions," even more "advanced in the realm of fiction" than the notion of the "divine right of kings."108 Never lacking in boldness, he goes right on to state his lack of interest in any of these "theories": ${ }^{109}$

The experimental jurist as such has little interest in the general theories advanced to explain the purposes of government as a whole or to justify certain lines of policy. As a scientist he must recognize that these expressions are largely fictional. While he might possibly desire to examine the factual effectiveness of various devices used to disseminate these fictions in persuading the public to submit to the general policies of a particular government, his immediate attention preferably would be directed toward the effect of a particular law in accomplishing the real purpose for which it was created.

It is much safer, he says, to have "enlightened theories of law and government carefully worked out by rational experimental processes rather than be left to rely on the speculation of cloistered philosophers or the mad dreams of imprisoned fanatics."110

Whatever the misgivings inspired by the first part of Beutel's book, and they are many, they are allayed by the following consideration. The problem he uses to illustrate the methods of experimental jurisprudence has nothing to do with such things as a "general constitutional revision," but merely a Nebraska shade-tree statute; and the problem that occupies him throughout Part Two of the book concerns not the "grandiose plans which so intrigue the theoretical policymaker," but merely the passing of bad checks. Rule by experimental jurisprudence is not imminent, and there would seem to be little danger of its ever coming about, at least in all its manifestations. Nevertheless, what this book represents must be taken seriously: an impatience with the "unscientific" aspects of democratic government.

It would be possible, by careful selection, to present a thesis from his book that is not wholly incompatible with a certain view of democracy, one in which experimental jurisprudence appears as no more than a means of effecting or of institutional-

\footnotetext{
${ }^{207}$ Id. at 75 .

${ }^{108} \mathrm{Id}$. at 62.

${ }^{100} \mathrm{Id}$. at 63 .

${ }^{110} 1 d$. at 32 .
} 
izing a pragmatic ethics. ${ }^{111}$ In one respect, Beutel, in this line of argument, is merely restating a thesis that Roscoe Pound has professed since at least I922 and the publication of his Introduction to the Philosophy of Law. In telling us why experimental jurisprudence has no need of the term "value" for example, Beutel says that all "that is necessary is to discover the actual condition of the interests or demands of people in society to expose the need for granting the demands which they make, and to choose the legal devices which will be useful for making possible the fulfillment of the desires represented by the choices, with the least social friction."112 It would be unjust to Beutel to deny this element of his thought, but it would be untruthful to suppress the other element or to suggest that the two can somehow be reconciled.

Beutel is at his best when he is discussing the bad check problem. At other times he is confused, naîve, and altogether innocent of any understanding of theoretical problems, the very problems he discusses and disposes of in so summary a fashion. In fact, his study is a caricature of a serious discussion of the themes he deals with. Should he take umbrage at this statement, we could reply with his own argument: we are not responsible for what we say; man is not free, he is wholly in and of nature, as much as "an animal or a stone," and only a fool would lodge a protest against an animal or a stone for behaving as animals and stones behave. We could defend on this ground but won't, because it is highly doubtful that Beutel understands the implications of his assertion. ${ }^{113}$

\section{Conclusion}

Beutel's book is an almost perfect illustration of the sort of misuse of science that Lee Loevinger must have had in mind when he said that "science has contributed little, if anything, to the solution of social or legal problems," partly because it has been asked "the wrong questions, and set ... the wrong tasks," and specifically because science has been expected "to distill social policies from a test tube or a retort, much as Aladdin summoned a genie by rubbing a magic lamp."114 Loevinger makes no such claim for his "jurimetrics," which he nevertheless describes as "the most promising avenue of legal progress in the contemporary world." Rather than to replace the "cloistered philosophers" and the "ffictions" of the Declaration of Independence, science's most "promising and immediate contribution . . . is in automatic information retrieval." "15 computers will not solve legal problems, and will not make judging obsolete, but they will assist in the solutions and in the task of judging, just as social scientists can provide information that is not available from the computers but may be needed for the wise solution of the problems that confront the courts and the law generally. Such techniques as the public opinion survey

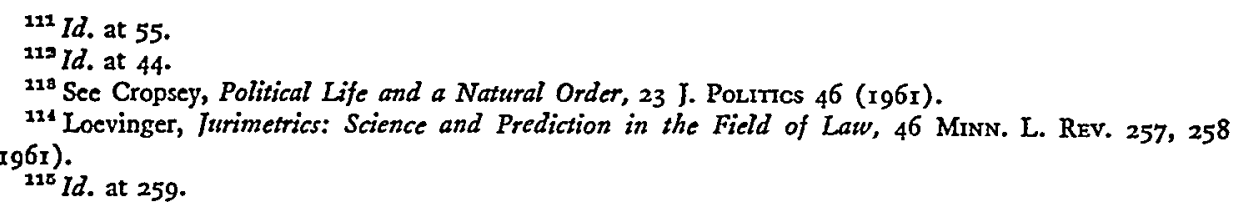


undoubtedly facilitate the gathering and collating of information, and there will be times when such information is needed by the law. This may not be an exalted role, but as society becomes ever larger and more complicated, it is necessary and an appropriate role.

Doubtless there have been "phenomenal technical and scientific" advances during the past century, as Beutel says, and that there is a "social lag"; and perhaps it is true that the "general science and art of lawmaking" has not developed "since the days of the Roman Empire"; 116 but this is no reason for law to imitate physics or engineering. On the contrary, a grasp of the fundamental problems might reveal that there is an irresolvable tension between science, in its old or its new sense, and politics, and that any attempt to resolve the tension is likely to have terrible consequences in the political world; that the political world must be ruled not by science but by prudence. This requires at a minimum the recognition that there will always be a "gap" between theory and practice, and that the recalcitrant or intractable political problems cannot be wholly resolved-at least, not by a government of free men. True, Socrates said that "cities will never have rest from their evilsno, nor the human race... until philosophers are kings, or the kings and princes of this world have the spirit and power of philosophy";117 but Socrates, who failed even in his attempt to rule his wife, Xanthippe, knew and taught that it is extremely unlikely that the conditions required for the rule of the wise will ever be met. As Leo Strauss has said: ${ }^{118}$

What is more likely to happen is that an unwise man, appealing to the natural right of wisdom [to rule] and catering to the lowest desires of the many, will persuade the multitude of his right: the prospects for tyranny are brighter than those for rule of the wise. This being the case, the natural right of the wise must be questioned, and the indispensable requirement for wisdom must be qualified by the requirement for consent. The political problem consists in reconciling the requirement for wisdom with the requirement for consent.

Legal scholars, and even practicing lawyers, know these exceedingly important things; they therefore have more to teach to the new scientists than the new scientists have to teach them.

\footnotetext{
126 BevTEL, op. cit. supra note 99, at 3.

${ }_{117}$ Plato, The Republic 473 D-E.

${ }^{118}$ Leo Strauss, Natural Right and History I4I (1953).
} 